\title{
The Nurses Memorandum of 1938: A first step in the development of action learning?
}

\author{
Tom Bourner, Brighton Business School, University of Brighton \\ Cheryl Brook, Faculty of Business and Law, University of Portsmouth \\ Mike Pedler, Henley Business School, University of Reading
}

\begin{abstract}
This article concerns the origins of the idea of action learning, especially the claim by Revans that his Memorandum on 'The Entry of Girls into the Nursing Profession' in Essex hospitals written in 1938 was the first step in the development of action learning. Whilst Revans repeatedly made this claim, there is no evidence in the actual words of the Memorandum to support it, and he never explained the basis for his belief. Why Revans saw this paper as a first step is therefore a mystery. In this paper we examine the circumstances of the production of the Memorandum to find possible answers. After discussing the evidence we conclude that Revans' claim is based on upon the ideas and insights which occurred to him in 1938 in his research and thinking, rather than upon what he actually wrote. We also suggest some defining aspects of action learning can be traced back to ideas first stimulated in the research and production of the 1938 Memorandum, including the importance of firsthand knowledge in tackling organisational problems; the limitations of expert knowledge in complex conditions; the impact of hierarchy on the flow of knowledge; the importance of problem ownership in bring about action for improvement and the primacy of learning in the processes of problem-solving and innovation.
\end{abstract}

Keywords: First-hand knowledge; expert knowledge; authority; hierarchy; innovation

\section{Introduction}

Reg Revans repeatedly stated that the first step in the development of action learning was a memorandum on the recruitment and education of trainee-nurses that he wrote in 1938 (Revans 1982, 1988, 1995). Yet, on reading that 1938 paper, it is not at all apparent how it relates to action learning, or to its development, or even to its underpinning ideas. Why Revans saw the production of the Nurses memorandum as the start of action learning is something of a mystery. In this paper we attempt to shed some light on this and to offer possible explanations.

In 1981, when action learning was moving from being a maverick form of management education to becoming a mainstream method of management development, Revans was assembling a collection of papers spanning more than 40 years on The Origins and Growth of Action Learning (1982). Revans believed that the evolution of action learning: “...is traced in these unedited papers, presented as they were written up to half a lifetime ago." (Revans, 1982: 2). An early chapter, 'The Entry of Girls into the Nursing Profession' is described in the Table of Contents as: "A first step, taken in 1938, to work proving its success in 1981" (1982: VII).

A few years later, Revans confirmed that the roots of his thinking on action learning lay in the production of the 1938 paper by celebrating it with the publication of The Golden Jubilee of Action Learning (1988). In 1995, aged 88, in Disclosing Doubts, his last substantive 
publication, he affirmed yet again that this is where the origins of action learning in Britain can be found. The first appendix of Disclosing Doubts reproduces most of the memorandum with the bold claim that: "The first responsible proposal to practise action learning ... to be found in the writings of Reg Revans is The Entry of Girls into the Nursing Profession. It was a memorandum to the Essex Education Committee in 1938 and most of it is reproduced here (sic)" (1995: A1). Yet no such proposal is evident in that paper, and despite his clear conviction, Revans never explained how the memorandum actually contributed to the beginnings of action learning. The wider literature on action learning provides no clarification. In their extensive account of the history and evolution of the idea, Boshyk \& Dilworth (2010: 123) reiterate Revans' claim that the document in question was "one of the important foundations for his thinking about action learning" but again without explanation of how this was so.

We begin with a consideration of Revans' background and development up until 1938, and follow this with an account of the circumstances and process that led to the production of the Nurses' memorandum. A discussion section then looks at issues and questions raised in this account, and leads to the conclusion section which offers a suggested explanation of the mystery. Why do we think this to be significant issue? First, because exploring this mystery of the origins may illuminate what was driving the development of Revans' action learning over 40 or 50 years; if we want to know where something is coming from (metaphorically) it can help to know where it came from (literally). Secondly, given that Revans never provided a single authoritative definition of action learning, studying the origins might clarify what is core and what is not. Furthermore, a better understanding of the starting point can aid the assessment of new developments in the unfinished project that is action learning (Pedler et al, 2005).

\section{Background}

Revans was born in Portsmouth in 1907 to a father who was a marine surveyor (later Principal Ship Surveyor for the Board of Trade) and a family with some other members connected to healthcare: his mother volunteered in the local hospital, his sister trained as a nurse and a brother trained as a doctor (Revans, 1987). The family moved to Birkenhead and then to London where Revans attended Battersea Grammar School and University College where he was an outstanding student, receiving a first class degree in physics (Barker, 2010). He was then awarded a postgraduate scholarship at Emmanuel College, Cambridge where he worked in the Cavendish laboratory (Boshyk \& Dilworth, 2010).

His research supervisor at Cambridge was J. J. Thomson, Professor of Experimental Physics, who had won a Nobel prize for the discovery of the electron, the first sub-atomic particle to be found, which promoted the study of nuclear physics as the leading edge of the science at that time (Seeger, 1986). Thomson had been Chair of the Royal Society and had led a British government review of the natural sciences in the school curriculum, the report which "advocated teaching which drew attention to everyday life and the natural phenomena of science" (Smith, 2010:191) and recommended that "science should be as closely connected with human interests as possible" (Thomson Report, 1918, para 47). The head of the Cavendish was Ernest Rutherford, another Nobel laureate, who saw science as a collaborative venture and who tried to establish a cooperative rather than a competitive culture in the laboratory. As he would later often recount, the young Revans, naturally competitive, even combative, and who had just represented Britain in the 1928 Olympics, was impressed by the willingness of these eminent scientists to learn with, and from, each other by recognising and disclosing their own ignorance and doubts.

On the completion of his PhD in 1935, Revans successfully applied for a post in the Education Department of Essex County Council where he was to be responsible for the development of technical schools and technical colleges. He was attracted to the position 
partly because of the Director of Education, John Sargent (later Sir) who was an advocate of progressive education and a leading proponent of technical education. The brief for the post included the development of technical education in colleges in Essex.

“...in 1935, I left Cambridge to help in the development of technical education by the Essex County Council; ... Essex was the first authority to insist upon supplying new modes of post-primary education, and it was to lend a hand with its campaign for innovation that I joined the education office as an assistant to Sir John Sargent (as he later became), the director of education to the County Council." (Revans, 1982: 18-19)

Sargent's expertise was widely recognised and in 1938 he left Essex to become education commissioner with the government of India, leaving Revans as the most senior person in the field of technical education in the Essex County Council. By the mid-1930s a nursing crisis was emerging in the County's hospitals, and in 1937 representatives of the Public Assistance Committee, Public Health Committee, Mental Hospitals Committee and Education Committee met to discuss it (Revans, 1982: 23). The County Medical Officer produced a report to the Public Health Committee highlighting the seriousness of the situation:

“... for many years past there has been a slowing down in the recruitment of nurses, and this seems to have been accentuated very considerably during the last year. I wish the committee to realise that we are confronted with an exceedingly serious position." (Revans, 1982: 23)

In his capacity as a technical education specialist Revans was asked to produce a paper on the recruitment, education and training of nurses. His response was the 1938 memorandum to Essex Education Committee on the 'The Entry of Girls into the Nursing Profession' which looked at nursing recruitment, the provision of pre-nursing courses in technical colleges including examinations and financial considerations (Revans, 1982).

\section{The Production of the Essex memorandum}

Faced with the problem of nursing shortages and the difficulties of recruiting trained nurses, the County Medical Officer looked for a solution from an expert and Revans was now the technical education specialist in the county's Education Department. And faced with the task of producing a paper on this issue, it occurred to Revans that he could learn from those with first-hand experience of it:

"... it crossed my mind that I was the one who had most to learn about what we were all trying to do ... or more precisely, about we claimed we were all trying to do" (Revans, 1988: 7).

In other words, when he was asked to produce the paper he had the idea that he could learn something useful from those with first-hand experience of the problem of the shortage of trained nurses in the hospitals. He decided to test this idea by going to visit the hospitals themselves "to learn what might actually be going on in them" (Revans, 1988: 7) which gave him opportunities to meet and talk with people with local knowledge in hospitals.

Where did the idea come from? Eighty years after the event that is, of course, impossible to say. However, there is circumstantial evidence that his family are implicated. Revans sister, Mary, was a nurse, his brother, John, was a junior doctor and his mother, Ethel, did volunteering work in hospitals including cleaning and organising 'cleaning parties' (Revans, 1987), so they all had first-hand experience of the situation of nurses in hospitals and the conditions in which nurses worked. Revans remained close to his mother all his life and his father had recently died (December 1936) so it is likely that his family were still in contact 
with each other in 1937. In the light of their first-hand experience of hospital conditions it would be surprising if they were not interested to hear of Reg's involvement in an enquiry into what to do about the shortage of nurses in hospitals. And it would be surprising too if that news did not trigger suggestions, opinions, advice and first-hand knowledge from members of his family with first-hand experience of the issue.

Whatever the source of the idea that first-hand experience can yield useful knowledge, the idea of testing it by visiting hospitals takes less explaining. As a scientist, educated at the Cavendish Laboratory, centre of experimental physics, Revans would have been trained to test ideas empirically if at all possible. Consequently, he took steps to visit the hospitals where the first-hand experience was located and hence the first-hand knowledge was to be found. The idea seems to have passed the test because when Revans was asked to produce a report (as an external expert on technical education) on education and training in the mining industry in 1944 he started by going to live and work with miners in Durham for several weeks to gain some first-hand experience (Times, 2003). "He starts this assignment by living with the miners and going into the coal pit to better understand the situation." (Boshyk \& Dilworth 2010: 124.)

\section{Hospitals and hierarchies}

The question arises as to why, when faced with the problem of a nursing shortage, the County Medical Officer and his colleagues, placed more value on Revans' external expertise in technical education rather than asking for the opinions of those actually working in the hospitals. There were two sides to the problem of nurse shortage: insufficient recruitment of nurses and inadequate retention of nurses. The inflow of trainee-nurses and the outflow of experienced nurses results from decisions made by prospective trainee-nurses and trained nurses respectively. These are the people with the knowledge needed to tackle the problem, yet the Country Medical Officer looked for a solution from an external expert. Why were the nurses and trainee-nurses themselves not consulted?

There were several obstacles to so doing in 1938. Trainee-nurses were young and presumed ignorant. Most would have left school at the age of 14 whilst most of the senior medical managers would have previously been health service consultants with at least 10 years more secondary and higher education. Secondly, nurses occupied a low position in the hierarchy of the hospital; as Revans later noted: wrote: "...public administration in general, and that of the social services in particular, is still dominated by the authoritarianism of the Middle Ages." (Revans, 1980: 36).

The language employed in the Memorandum is indicative of the existing power relationships; the education of nurses is referred to as 'instruction' which has a dual meaning, indicating both a method of training and an order or directive from someone in a higher position to another in a lower position in a hierarchy. Similarly, in the writing on management and organisation at that time, the terms 'superior' and 'subordinate' were common: superiors instructed subordinates, they did not consult them. Despite the fact that the nurses and trainee-nurses were the ones with the relevant first-hand knowledge, it was probably unthinkable at that time for senior managers to consult them on the problems of recruitment and retention.

What then is the argument for the young Revans taking a different view? Much of the evidence comes from his own reflections on experiences of some fifty years earlier, which allows for conjecture rather than proof. In his account of conversations with the older Revans, Barker (1998: 13) recalls that he reacted strongly to the hospital cultures that he encountered in his research for the Memorandum: 
"Revans set out to investigate the reasons why so many nurses were lost from hospitals during their early years. He found a culture that hardly encouraged them. The idea that 18-to 20-year-old girls could possibly have anything to contribute to how a hospital ward might be organized and patients better cared for was simply ludicrous in the eyes of their 'superiors'."

Hospitals remain hierarchical institutions, and were even more so in 1938. Authority resides at the higher levels, and like instruction, this word has more than one meaning; indicating the power to command and control and also the embodiment of expert knowledge or the right to authorise. Fresh from his long development as a scientist, and from his experiences in the collaborative and challenging climate of the Cavendish Laboratory, Revans would have learned to be sceptical of received views. A defining feature of science is its disrespect for authority as a justification for knowledge claims. The Royal Society, founded in 1660, adopted the motto nullius in verba or 'take nobody's word for it', and whilst, in epistemology, the term 'authority' refers to one of the traditional sources of justification for knowledge claims, scientific thinking places more weight on empirical evidence. In the context of the organisational problems of hospitals, or other institutions, the first-hand experience of those who work in them would be the nearest thing available to empirical evidence.

\section{The next step}

If the production of the Nurses Memo was the first step in the development of the idea of action learning then what was the second step? We have argued that the Nurses memo was the first step because it was through the production of that memorandum that Revans came to see the value of first-hand experience in generating first-hand knowledge which could be useful in tackling organisational problems ${ }^{1}$. And it was that which revealed the limitations of expert knowledge in the context of complex problems in organisations. We noted above that before he left the employment of Essex County Council he was asked, in 1944, to produce a report on education and training in the mining industry. His experience of producing the Nurses Memorandum is evident in both the process and content of the report he produced. He started the task by going to live and work with miners in Durham to gain first-hand knowledge from those with first-hand experience of mining.

"I actually went to work in the pits, worked with the men and I lived in their houses, if you can call them that, in the mining villages. I began to see very clearly that the complexities of trying to understand what was happening in the coal-mines was so great that it was virtually impossible for the people who said "we're in charge" to understand what the real problems were." (Revans, 1994, quoted in Boshyk \& Dilworth, 2010: 68)

His report, published in 1945, contained proposals for a staff college where managers in the industry could learn from each other by exchanging their first-hand knowledge. This proposal built on the idea of first-hand experience as a source of first-hand knowledge which could be used in tackling organisational problems. An extract of the report follows immediately the chapter on 'The Entry of Girls into the Nursing Profession' in his The Origins and Growth of Action Learning. This paper, 'A Staff College for the Mining Managers', went beyond the idea of experts learning from those with first-hand knowledge and potentially removed the need for experts altogether in the dissemination of first-hand knowledge. It is introduced by Revans as the "first clear statement, in 1945, of the need for managers to learn with and from each other in the face of common adversity" (Revans, 1982: VII). Revans suggested "that

\footnotetext{
${ }^{1}$ In his introduction to his chapter 'Action Learning and the Nature of Knowledge' in Revans (1982) he wrote uncompromisingly that "Knowledge that cannot be used is not knowledge at all." (Revans, 1982: XI).
} 
active managers would gain more with and from each other than from academic courses of most kinds; ..." (Revans, 1982: 30).

\section{Discussion}

This account of the production of the Nurses memorandum contains various clues and indications about the claim that this was a first step in the development of action learning. These include importance of first-hand knowledge in diagnosing organisational problems and the limitations of expertise, and raised questions about the problems of hierarchy structures and the primacy of new learning in the context of innovation and change.

In The Origins and Growth of Action Learning, Revans introduced the chapter on 'The Entry of Girls into the Nursing Profession' in the following way:

"it anticipates a social problem that was to engage him (Revans) for many years. In 1965 he became a research fellow of Guy's Hospital Medical School in order to introduce action learning as one diagnosis and therapy of the trouble he had met 27 years before.” (Revans, 1982: 23).

What was that trouble and what was the social problem it anticipated? Revans did not go on to explain further, but the argument in this article suggests that his experience of the deleterious effects of hierarchy and authoritarianism on the successful resolution of problems such as the nursing shortage in Essex in 1938 can be seen as prompting a search for an appropriate therapy that was to emerge later as an early form of action learning. Revans appointment to Guy's in 1965 heralded the start of the first large-scale testing of these ideas in the Hospital Internal Communications Project (Wieland and Leigh, 1971, Brook, 2013).

As well as the impact of hierarchy on the upward flow of communication and knowledge, it is also interesting to note that Revans, perhaps again as a result of his scientific training, was very careful in the way he defined the problem of the shortage of trained nurses or the question to be addressed. In the memorandum preamble he states: "It is not the responsibility of the Education Committee to ask what factors within the nursing service contribute to this state of affairs. If conditions of service are unattractive... the remedy lies only with the hospitals themselves." (Revans 1982: 22-23). In confining his brief to what was properly the responsibility of the Essex County Council Education Department, he was clearly aware that much of the causation and constitution of the problem of nursing shortages were likely to be found outside this brief and within the hospitals themselves and the wider context. It was not the responsibility of the Education Department to make proposals about the nursing service that might be contributing to the state of affairs. Revans duly confined his proposals for training intending nurses within the remit and domain of the Education Committee, i.e. schools and technical colleges. His query in the memorandum preamble about whether the responsibility for resolving this problem lay with the county's Education Committee or the hospitals themselves, suggests that he had some doubts about the efficacy of his scheme as a complete solution. This is speculative, but it seems possible that this questioning of the location of problem ownership, heightened his awareness of an issue later to become a central feature of his action learning, namely the insistence on the necessity of personal responsibility and risk in choosing problems and acting on them.

Alongside instruction in the technical colleges, Revans recommended a significant period of work experience for trainee-nurses. First-hand knowledge of current practice was necessary for the development of capable nurses. The programme of instruction would include "physiology, anatomy, biochemistry, dietetics, hygiene, first aid and so forth", but would also include visits to hospitals in their second year and two or three days of work experience in hospital in their third year and full-time work experience in their fourth/final year except for just one morning or afternoon per week at the technical college (Revans 1982: 27). His 
proposals thereby made provision for school-leavers without any first-hand knowledge of hospitals to get first-hand experience of the work in hospitals. This suggests that he regarded any provision based solely on school and college as inadequate to the task.

The significance and place of first-hand knowledge extends well beyond the needs of trainee nurses. As noted above, when asked to address the problem of the nursing shortage and make suggestions for its resolution, Revans recognised that it was he who had most to learn about "what we were all trying to do". The ambiguity of the situation and his uncertainties about it, led him not only to research the problem but also to the wider recognition "of the innovator's need to learn that has since taken me into so many fields" (Revans, 1988: 7). In an organisational context where "change management" so often remains a "top-down" process, this is a critical insight which informs the "bottom up" and democratic approach to social development that later became action learning.

In the early decades of the $21^{\text {st }}$ century it is easy to take for granted the value of first-hand knowledge. In the interwar years, old and venerable knowledge, flowing from privileged elites in the clergy, academy, the learned professions and so on, was much more valued than knowledge found 'on the shop floor'. After the second world war much greater value has been attached to first-hand knowledge, partly as a result of a shift in the epistemological paradigm to include knowledge formed in the service of action (Raelin 2009) including developments in action research, experiential learning and other practice-based approaches. The development of action learning can, with hindsight, be seen as an early part of that emergent paradigm (Pedler 2011: xxiv).

\section{Summary \& Conclusion}

We set out to understand why, despite the apparent lack of evidence within the actual document, Revans repeatedly insisted from 1982 onwards that his1938 paper on the recruitment and education of trainee-nurses was the first step in the development of action learning. However, Revans had also made earlier claims; in 1977 Revans gave a lecture titled Action Learning: its Silver Jubilee 1952-1977 taking its origins back to 1952, after which he saw it as going back to 1945 with his proposal for a Coal Industry Staff College and in Origins and Growth (1982) and thereafter he claimed the first step was taken in 1938. We might speculate that during the 1960s and 70s, Revans was more concerned with the developing a reliable practice of action learning than he was about the origins of its foundational ideas. Perhaps it was only later, whilst producing the Origins and Growth of Action Learning (1982) and reflecting on its history, that he traced the origins back to the Memorandum. His later statement that the Nurses Memorandum was "The first responsible proposal to practise action learning" (Disclosing Doubts 1995: A1) is less credible. The idea is nowhere manifest in the Memorandum itself and there is no proposal to be found in that paper that constitutes a recognisable practice of action learning.

If the case for the seminal place of the Nurses memorandum is rejected then we are left with an alternative possibility that Revans included it in his 1982 book, The Origins and Growth of Action Learning, in order to claim a longevity and pedigree. The 1938 paper is subsequently celebrated as marking fifty years in the development of action learning in the Golden Jubilee (1988). Revans often remarked that action learning was not new in a fundamental sense, but was based on "immemorial wisdom ", frequently quoting ancient philosophical sources including the Bible and The Buddha (1982: 529-545). In a field like management and organisation development, notorious for its short-lived fads and fashions, it could be argued that this is a useful protective strategy.

Whilst this reading cannot be entirely ruled out, we have argued that the thinking that went into the 1938 Memorandum has a substantial claim to be seen as the genesis of Revans' formulation of action learning. In simply reading the words of the 1938, it is not at all apparent how they relate to action learning, its development, or indeed, its underpinning ideas. We have argued that 
understanding its contribution to action learning requires some knowledge of the circumstances of its production. As with much in the history of ideas, it is difficult to find hard empirical evidence of the development of an idea and our conclusions are therefore necessarily tentative.

On the basis of the above account, we propose that it is possible to trace some defining aspects of action learning back to ideas first stimulated in the research and production of the 1938 Memorandum. These include the importance of first-hand knowledge in tackling organisational problems and the limitations of expert knowledge in complex conditions. We also suggest that this raised questions about the impact of hierarchy on the flow of knowledge; the importance of problem ownership in bring about action for improvement and the primacy of learning in the processes of problem-solving and innovation. The development of these insights came later and notably in the Hospital Internal Communications project 1965-8, another important step in the development of what we now recognise as action learning (Pedler, 2006; Brook, 2010, 2013). All of these issues remain relevant to the management of organisations and for tackling the wider problems in society.

We suggest that Revans' claim for the Nurses Memorandum as "a first step in the development of action learning" is based on the ideas and insights which occurred to him in 1938 in his research and thinking, rather than upon what he actually wrote in that paper. The Memorandum was necessarily circumscribed by the limitations of the brief and what was "properly" the responsibility of the Education Committee rather than the health authority. From his recollections of fifty years later it seems reasonable to conclude that he had thoughts at the time that he later recognised as seminal to action learning.

\section{References}

Barker, A. (1998) 'Profile of Action Learning's Principal Pioneer-Reginald W. Revans' Performance Improvement Quarterly, Vol. 11. No. 1 pp 9-22.

Barker, A. (2010) 'Remembering Reg Revans: Action Learning's Principal Pioneer', Chapter 2 in Action Learning: History and Evolution edited by Boshyk and Dilworth (2010), Hants: Palgrave Macmillan.

Boshyk, Y and Dilworth, R. (2010) Action Learning: History and Evolution Hants: Palgrave Macmillan.

Brook, C. (2010) 'The role of the NHS in the development of Revans' action learning: correspondence and contradiction in action learning development and practice' Action Learning: Research and Practice, 7(2), pp.181-192.

Brook, C. (2013) 'What shaped action learning in the UK? Accounting for the development of action learning as a managerial and organizational development practice', Management and Organizational History. Vol. 8, No. 3, pp. 231-244.

Pedler, M., Burgoyne, J. and Brook, C., (2005) 'What has action learning learned to become?' Action Learning, 2(1), pp.49-68.

Pedler, M. (2006) 'A 'classic' review: organisational change in hospitals: the hospital internal communications (HIC) project, 1965-68', (Review article) Action Learning Research and Practice, Vol. 3, No. 1 pp. 107-122.

Pedler, M (2011) 'The State of the Art' in Action Learning in Practice 4th Ed. Farnham: Gower pp. xx1 - xxvii

Raelin, J (2009) 'Seeking conceptual clarity in the action modalities' Action Learning: Research and Practice Vol. 6 (1) 17-24

Revans, R. (1938) 'The Entry of Girls into the Nursing Profession, Memorandum to Essex Education Committee, 1938', chapter 4 of Revans R. (1982).

Revans, R. (1977) Action learning: its silver jubilee, 1952-1977. 1977. Inaugural Lecture, Yorkshire and Humberside Regional Management Centre.

Revans R. (1982) The Origins and Growth of Action Learning, Bromley: Chartwell-Bratt. 
Revans, R. (1988) The Golden Jubilee of Action Learning: A collection of papers written during 1988. Manchester Action Learning Exchange, University of Manchester, Manchester Business School.

Revans, R. (1987) 'Action learning in brief' Address by Reg Revans, ICMB President Emeritus at the opening of the Revans Action Learning Workshop on 18 December, 1987. Retrieved from http://www.imc.org.uk/imc/action.htm

Revans, R. (1994) Videotape of a talk by Reg Revans at Virginia Commonwealth University, February, 1994 (referenced in Boshyk and Dilworth, 2010).

Revans, R. (1995) 'Disclosing doubts' In A report of the First International Action Learning Mutual Collaboration Congress, 17-25 April, 1995.

Seeger, R. (1986) "The American Science Affiliation" at http://www.asa3.org/ASA/PSCF/1986/JASA6-86Seeger.html accessed pm 03/01/2017.

Smith, E. (2010) 'Is there a crisis in school science education in the UK?' Educational Review, 62(2), pp 189-202.

Times (2003) 'Obituary: Reginald Revans: Management guru who taught executives to value experience over theory and put people first.' London: The Times, 21 February 2003.

Thomson Committee (1918) Report of the Committee to Enquire into the Position of Natural Science in the Educational System of Great Britain, London: HMSO.

Wieland, G F \& Leigh, H (1971) Changing Hospitals: A Report on the Hospital Internal Communications Project. London: Tavistock. 